\title{
TERRORISM, PROSCRIPTION AND THE RIGHT TO RESIST IN THE AGE OF CONFLICT
}

\author{
Mark Muller $Q C^{*}$
}

This paper focuses on the international community's response to the increased perceived threat of terrorism since 9/11 and how the so-called "war on terror" has affected our understanding of what constitutes terrorism. It briefly details some of the major legislative changes that have been enacted and examines the impact of counter-terror strategies on certain unresolved legal issues that have historically dogged the international community's efforts to arrive at an internationally agreed definition of terror. This includes the relationship between terrorism and the right to self-determination, the emerging right to democracy, and the existence of a license to use force as a last resort against an oppressive regime. The paper explores how the failure to resolve the relationship between these international legal principles has seriously undermined the efficacy of certain proscription regimes adopted around the world. It examines whether proscription regimes are in danger of disproportionately interfering with certain fundamental freedoms thereby reducing the scope for conflict resolution between aggrieved parties engaged in violence around the world.

\section{INTRODUCTION}

Over the last six years the international community has witnessed a massive increase in both international and domestic legislation concerning terrorism. The catalyst for much of this legislation was of course the tragic events of 9/11 although the process of proscribing so-called terror movements was gathering pace before the attacks by Al Qaeda.

The engine powering this recent legislative onslaught is Security Council Resolution 1373 passed of 28 September 2001. ${ }^{1}$ This Resolution imposed

\footnotetext{
* Garden Court Chambers, London. Took Silk on 16 October 2006. Was previously Head of Chambers at 10-11 Gray's Inn Square between 1998-2006. Currently Chair of the Bar Human Rights Committee (BHRC), Chair of the Kurdish Human Rights Project (KHRP), a founding trustee of the Delfina Foundation dedicated to East/West reconcilation through arts and culture, and a patron of the Zimbabwe Defence and Aid Fund.

${ }^{1}$ Press Release SC/7158 - Security Council unanimously adopts wide - ranging antiterrorism resolution calls for suppressing financing, improving international
} 
extensive obligations on States to prevent and counter terrorism and established a Committee of the Security Council to monitor its implementation. Significantly, the Resolution required States to ensure that "terrorist acts are established as serious criminal offences in domestic laws and regulations and that the punishment duly reflects the seriousness of such terrorist acts," ${ }^{2}$ irrespective of whether such acts are caught by ordinary existing criminal provisions. Resolution 1373 not only reflected the worldwide revulsion felt about the attack on the twin towers in New York, it also catapulted the issue of terrorism onto the international agenda in a way not seen before.

Just eight days earlier, on 20 September 2001 President Bush set the tone when he declared: "Either you are with us, or you are with the terrorists. From this day forward, any nation that continues to harbour or support terrorism will be regarded by the United States as a hostile regime." 3 This declaration had a huge impact on state practice towards countering terrorism. Hitherto the lack of any internationally agreed definition of terrorism was legally inconsequential as no international rights or duties hinged on the term "terrorism". All previous international conventions on terrorism were act specific and did not generically define who was a terrorist and who was not. However, President Bush's clarion call changed all of that for good. It effectively required numerous States to define its position in relation to numerous dissident groups and armed struggles around the world by pressuring states to adopt various proscription regimes.

The question today is how has President Bush's so-called "war on terror", together with the counter measures adopted by various states pursuant to Resolution 1373, affected the debate about what constitutes terrorism? Are we any forward in achieving an international consensus about what constitutes and what does not constitute terrorism? For example, what is the current status of the right to self-determination and other fundamental freedoms protected by international law in relation to the global fight against terrorism? How has the recent swathe of domestic state anti-terror legislation affected the status of any evolving right to democracy or to resist state oppression through violence as a last resort? What is the legal status of State sponsored terrorism? The answers to these questions will have profound consequences for the global fight against terrorism in the future.

cooperation resolution 1373 (2001) also creates committee to monitor implementation www.un.org/News/Press/docs/2001/sc7158.doc.htm

2 Acting under Chapter VII of the Charter of the United Nations 2 (e).

3 "Freedom at War with Fear" - Address to a Joint Session of Congress and the American People - http://www.whitehouse.gov/news/releases/2001/09/200109208.html 


\section{THE DEFINITION OF TERRORISM}

What is perhaps most revealing about this global fight is that despite the plethora of domestic anti-terror legislation passed by member states since Resolution 1373 the international community is still nowhere further in agreeing a definition of "terrorism". But whereas beforehand the consequence of failing to agree a definition of terrorism was largely academic today it has profound consequences legal, social and political consequences.

The inability to define terror has dogged the international community for 60 years. According to Kalliopi K Koufa, the UN Special Rapporteur on Terrorism and Human Rights, 109 definitions were put forward between 1936 and $1981{ }^{4}$ However, none were universally acceptable. The 1972 ad hoc committee of the UN General Assembly singularly failed to agree a Draft Comprehensive Convention or a definition of terrorism due to divisions over the status of national liberation movements. The 1996 ad hoc which was established pursuant to General Assembly Resolution 51/210 attempted to build on a non-binding definition of the Assembly contained in its 1994 "Declaration on Measures to Eliminate International Terrorism" but to also little effect. This failure to agree a comprehensive definition has led instead to the development of specific international conventions dealing with specific acts of terror. Thus, since 1963 there have been at least twelve international conventions dealing with aspects of "terrorism" yet none contain an internationally agreed definition. Even the most recent 1999 UN International Convention for the Suppression of Terrorist Bombings ${ }^{6}$ fails to define "terrorism."

As noted above, such lack of clarity has continued even after 9/11. Both UN Security Council Resolutions $1368^{7}$ and $1373^{8}$ do not define "terrorism". Although 1373 states that any act of international terrorism constitutes a threat to international peace and security and requires member states to combat terrorism by all means, it does not clarify what it means by the term "acts". As Judge Gilbert Guillaume, former President of the ICJ, rightly observes: "the international community has not been able to reach an agreement on such a definition of terrorism." 9 Such failure has moved, Rosalyn Higgins, another Judge at the International Court of Justice, to comment that: "terrorism is a

\footnotetext{
${ }^{4}$ Working Paper K K Koufa 26 June 1997.

5 General Assembly A/RES/51/210 - 17 December $1996-88^{\text {th }}$ plenary meeting. $51 / 210$ measures to eliminate international terrorism recalling its resolution 49/60 of December 1994 - http://www.un.org/documents/ga/res/51/a51r210.htm.

${ }^{6}$ Adopted 9 December 1999.

${ }^{7}$ Adopted 12 September 2001.

${ }^{8}$ Adopted 28 September 2001.

9 G Guillaume, "Terrorism and International Law" International and Comparative Law Quarterly (2004), 53:537-548.
} 


\section{TERRORISM, PROSCRIPTION AND THE RIGHT TO RESIST IN THE AGE OF CONFLICT}

term without any legal significance. It is merely a convenient way of alluding to activities, which States or individuals widely disapproved of."10 Yet, Rosalyn Higgins' dictum is, with respect, out of date given the post 9/11 "legislative environment". The definition of terrorism may remain a term without legal significance in so far as its construction is uncertain from a strictly legal point of view, but there is nothing uncertain or legally insignificant about its consequences for those deemed to be caught by new state anti-terror legislation.

In fact, the continued difficulty of formulating an objective definition of terrorism, and the resulting potential for arbitrary political decisions, was recently considered post 9/11 in the decision of Suresh $v$ Canada (January 11, 2002). ${ }^{11}$ The Supreme Court of Canada considered an argument that the term "terrorism" was so subjective in its meaning as to be "void for vagueness". Although the Court rejected the challenge, it emphasised the risk of abuse where a legal definition depended on an essentially political judgment:

"One searches in vain for an authoritative definition of "terrorism"...[T]here is no single definition that is accepted internationally. The absence of an authoritative definition means that, at least at the margins, 'the term is open to politicised manipulation, conjecture and polemical interpretation.'...Even amongst those who agree on the definition of the term, there is considerable disagreement as to whom the term should be attached...Perhaps the most striking example of the politicised nature of the term is that Nelson Mandela's African National Congress was, during the apartheid era, routinely labelled a terrorist organisation, not only by the South African government but by much of the international community." 12

The Court considered that the essence of the term, as internationally understood, was reflected in Article 2(1)(b) of the International Convention for the Suppression of the Financing of Terrorism (UN General Assembly Resolution 54/109, 9 December 1999). This defines terrorism as any "act intended to cause death or serious bodily injury to a civilian, or to any other person not taking an active part in the hostilities in a situation of armed conflict, when the purpose of such act, by its nature or context, is to intimidate a population or to compel a government or an international organisation to do

\footnotetext{
${ }^{10}$ Professor Bill Bowring http://mujahedin-e-khalq.org/MEK$\mathrm{MKO} /$ index.php?option=com_content\&task=view\&id=29\&Itemid=31

${ }^{11}$ Suresh v Canada (Minister of Ctizenship and Immigration), [2002] 1 SC R 3, 2002 SCC1.

${ }^{12}$ Para.94 - http://csc.lexum.unmontreal.ca/en/2002/2002scc1.html
} 
or abstain from doing any act." "13 In the Court's view, this definition "catches the essence of what the world understands by 'terrorism'."

The Supreme Court naturally recognised that it was open to a national Parliament to adopt a different or more detailed definition for the purposes of domestic legislation. However, it noted that the broader the definition becomes, the greater is the risk of arbitrary and "manipulated" application. The question is how much does it matter if individual states adopt a broader definition? Is the failure to agree an internationally recognised definition really that important?

\section{THE DANGERS OF OUTSOURCING OF THE DEFINITION OF TERROR TO MEMBER STATES}

Many observers believe the failure to agree a definition since $9 / 11$ has produced profoundly dangerous legal effects. This is because Security Council Resolution 1373 has effectively outsourced the definition of terrorism to member states to define "terrorism" domestically without limitation. The hackneyed phrase "one man's terrorist is another man's freedom fighter" has been replaced with the dictum "one state's terrorist is another state's freedom fighter." Whether a person or group is terrorist in nature is no longer a matter of personal political opinion or of international debate but of national law as defined by the particular law of the state in which one resides.

Since 2001 the UK, EU and the USA have enacted extensive terror legislation including new definitions of what constitutes "terrorism". Within two months of $9 / 11$ the Bush Administration rushed through the USA Patriot Act. ${ }^{14}$ The UK enacted the Crime and Security Act 2001. While on 13 June 2002 the EU adopted its own Framework Decision that required member states to take legislative steps to implement its terms. Since then Australia, Belarus, China, Egypt, India, Israel, Jordan, Kyrgyzstan, Macedonia, Malaysia, Russia, Syria, Uzbekistan and Zimbabwe have all followed suit. Much of this legislation is the proscription regimes introduced. Moreover, this legislative frenzy has been conducted within the context of the Bush Administration's clarion call. This has led many states to proscribe groups that are an anathema to the United States as a matter of foreign policy. This in turn has had a significant impact on the protection of fundamental freedoms and internationally recognised principles of international law such as the right to self-determination.

For example the European Union's attempt to establish a common legal definition of terrorism is also linked to an attempt to abolish extradition

\footnotetext{
${ }^{13}$ Article 2(1)(b) of the International Convention for the Suppression of the Financing of Terrorism.

${ }^{14}$ USA Patriot Act - March 92006 - http://www.whitehouse.gov/infocus/patriotact/
} 


\section{TERRORISM, PROSCRIPTION AND THE RIGHT TO RESIST IN THE AGE OF CONFLICT}

between member states in favour of an expedited procedure. This mirrors the concerted effort on the part of a number of states over the last six years to eliminate the "political offences" exception in relation to "terrorism", which due to the absence of an internationally agreed definition, is now defined by each state. This has been coupled with measures to exclude "terrorists" from asylum and refugee protection. It is therefore, perhaps unsurprisingly that many states have responded in a way that best suit their interests, and have shown little hesitation in defining terrorism widely and proscribing various organisations without recourse to the international recognised legal norms, including the principle of self-determination.

\section{THE EFFECT OF OUTSOURCING ON THE PRINCIPLE OF SELF- DETERMINATION}

The right to self-determination is recognised under customary international law as jus cogens. It is also recognised in common Article 1 of the International Covenant on Civil and Political Rights and the International Covenant on Economic, Social and Cultural Rights which provide:

"All peoples have the right to self-determination. By virtue of that right they freely determine their political status and freely pursue their economic, social and cultural development." 15

It is unnecessary, for present purposes to summarise the emergence of the right to self-determination in international law. It is sufficient to note that it is now accepted that peoples have a right to self-determination in three situations: where they are under colonial domination; where they are subject to alien military occupation; and where they are a distinct racial group denied equal access to government (so-called "racist regimes"). The rules of international law:

(a) Forbid a state in such circumstances from taking military or other coercive action to suppress the lawful exercise of the right to selfdetermination;

(b) Recognise that peoples exercising the right to self-determination have, in the last resort, a licence to engage in armed conflict to protect themselves, and to prevent the violent suppression of the exercise of the right to self-determination by the oppressor state;

${ }^{15}$ United Nations International Covenant on Economic, Social and Cultural Rights Part 1 Article 1(1). 
(c) Forbid third states from affording support to oppressive states so as to assist them in suppressing the exercise of the right to selfdetermination.

In Self-Determination of Peoples by Professor Antonio Cassese, ${ }^{16}$ former President of the International Criminal Tribunal for the Former Yugoslavia, the position in international law is summarised as follows:

"[I]t now seems well established that international law bans not only the use of military force by states for the purpose of denying selfdetermination to a colonial or foreign or a racial group, but also other forms of forcible action designed to pursue the same goal. The first case occurs when a state uses armed violence to maintain or enforce its denial of self-determination. The second case is when a state wielding authority over a colonial people, besides failing to take all the necessary measures for enabling the people to exercise its rights to self-determination, also sets up institutional, coercive mechanisms designed to prevent the implementation of self-determination (or in the course of its military occupation of a foreign country establishes procedures and takes measures designed to thwart any attempt by the occupied people to exercise its right to self-determination; or alternatively sets up in its domestic legal system institutions which deny a racially discriminated group equal access to government).

In both classes of cases the denial of self-determination has a twofold legal relevance under international law: firstly, it constitutes a violation of international legal rules; secondly, as we shall shortly see, it legitimises the resort to military force by the organisation representing the oppressed people or group...

The importance of these normative developments should not be underestimated: the international community has gone so far in its protection of self-determination as to prohibit not only the use of military force by the oppressive state, but also what could be termed 'institutionalised violence', namely all those measures, mechanisms, and devices destined to prevent peoples or racial groups from exercising their right to self-determination...

The UN Charter neither authorises nor bans the use of force by dependent peoples (or rather, by liberation movements representative

${ }^{16}$ A Cassese, Self-Determination of Peoples: A Legal Reappraisal (Cambridge, Cambridge University Press,1998). 


\section{TERRORISM, PROSCRIPTION AND THE RIGHT TO RESIST IN THE AGE OF CONFLICT}

of those peoples) for the realisation of external selfdetermination...Although no legal right proper was thus bestowed on liberation movements to resort to force, gradually the view emerged among states that nevertheless resort to force by these movements was not in violation of the general ban on force that had meanwhile emerged in the world community...However, the attitude of the world community was qualified by a basic condition: that resort to force by liberation movements should only be effected as a response to the forcible denial of self-determination by the oppressive Power, that is by the refusal of the latter State, backed up by armed force, or even coercive measures short of military violence, to grant selfdetermination to colonial peoples (or to peoples subjected to foreign military occupation or to organised racial groups denied equal access to government). Furthermore, the world community did not go to the lengths of conferring a legal right proper on liberation movements, but only granted a licence to use force...

On the other hand, third states must refrain from assisting a state that forcibly opposes self-determination. Any substantial help to the oppressive state, be it military or economic in nature, is regarded as illegal under current international law." 17

These developments are reflected in two key UN resolutions:

(a) The 1970 UN General Assembly Declaration on Principles of International Law concerning Friendly Relations and Cooperation among States in accordance with the Charter of the United Nations (Resolution 2625); and

(b) The 1974 UN General Assembly Definition of Aggression (Resolution 3314).

They are also reflected in the UN International Law Commission's Draft Articles on Responsibility of States for Internationally Wrongful Acts. ${ }^{18}$

Notwithstanding the status of the self-determination principle, however, the counter terrorist strategy deployed by many States since $9 / 11$ has had a profoundly corrosive affect upon the operation of the principle of selfdetermination and, by implication, the international community's commitment to support groups struggling for democracy against oppressive regimes. It has

\footnotetext{
${ }^{17}$ As above $\mathrm{p} 200$.

18 UN International Law Commission's Draft: Responsibility of State for Internationally Wrongful Acts 2001.
} 
certainly brought into sharp relief the international community's historically schizophrenic attitude towards the principle of self-determination and its deep distrust about its further application. As we know, there has always been an uneasy relationship between the principle of self-determination and the phenomenon of terrorism. There is a discernible tension between calls for a wider concept of terrorism and how that interplays with the recognition of the principle of self-determination, involving as it does a potential license to deploy force as a last resort in defence against an oppressive regime.

It is this tension that lay at the heart of the international community's inability to come to an agreed consensus about what constitutes terrorism before 9/11. It is why the Ad Hoc Committee on International Terrorism, established by the UN General Assembly to find a unanimously acceptable definition of terrorism, and which met from 1972 to 1979, was singularly unable to reach a consensus on a definition of the term terrorism. On the one hand many former colonised states were adamant that the legitimate actions of national liberation movements should not be confused with terrorism. On the other hand, many other states were deeply suspicious of extending the principle to situations unrelated to the decolonisation process. Such suspicion only increased after decolonisation. Thus, despite self-determination being recognised in UN treaties and attaining the status of a peremptory norm in international law there has been a concerted and consistent attempt to limit its external application. ${ }^{19}$

It is for this reason that certain commentators argue that the outsourcing of the definition of terrorism to nation states since 2001 is a particularly dangerous development given the backdrop of these states lack of respect of thee right to self-determination. Too many states have a vested interest in down playing the right or not legally protecting the right to self-determination - precisely because of their own concerns about their own minorities or indigenous peoples or those of their allies.

Underlying this entire approach is the desire to reinforce the supremacy of the nation state and its sovereignty at the expense of other principles of international law, which seek to limit such state authority. Far from seeking to protect the principle of self-determination or democracy, since 2001 member states have used the opportunity presented by the upsurge in terrorism to further relegate its practical effect. Time and again they have ignored these

\footnotetext{
${ }^{19}$ The ICJ has virtually denuded the right of practical effect by (1) equating the term "peoples" with the "government of a whole territory"; and (2) through (the "uti possidetis") rule that the exercise of self-determination must not involve changes to existing frontiers except where relevant nation states' consent. This conflated territorial constraint has effectively disenfranchised minority peoples in a majority in a province or part of a state from invoking the right of external self-determination. (One need only take a cursory glance at the Namibia Case to understand just how far the principle has been neutered).
} 
rights preferring instead to define terrorism in its broadest sense thereby giving governments the widest possible discretion to prohibit groups suspected of falling within that broad definition. This is because the right of self-determination with its suggestion that peoples of a territory can determine by a free and genuine vote the political status of their homeland either through independence, autonomy or integration with another state - presents a very threat to the power and authority of the nation state.

Over the last six years there has been a demonstrable effort on the part of numerous states to deny or give succour to any liberation or resistance movement who prey in aid of the principle of democracy or selfdetermination in their purported fight against oppressive states. On the contrary, movements who seek to invoke the principle are now routinely criminalised through proscription. This has huge consequences for numerous struggles around the world and for those organisations involved in them, such as the Palestinian search for statehood. Thus, the continued failure of the international community to reach an agreed consensus about what constitutes terrorism assumes much greater importance than at any time before September 2001.

\section{THE RIGHT TO DEMOCRACY AND OR RESIST AN OPPRESSIVE REGIME}

This attitude towards self-determination is replicated by many States attitude towards those groups who seek to resist oppressive regimes in support of democratic change. Most domestic provisions concerning terrorism and proscription fail to recognise any right to resist, rebel, or take up arms as a last resort in support of democracy.

This is particularly ironic given the international community's commitment to the principle of democracy. Both the General Assembly and the UN Commission on Human Rights have described terrorism as aimed at the destruction of democracy or the destabilising of "legitimately constituted Governments" and "pluralistic civil society." Other resolutions state that terrorism "poses a severe challenge to democracy, civil society and the rule of law." The 2002 EU Framework Decision, the 2002 Inter-American Convention, and the Draft Comprehensive Convention are similarly based on the premise that terrorism jeopardises democracy. While the jurisprudence of the European Court of Human Rights has consistently upheld the principles of democracy and pluralism as constituting the cornerstone of the Convention which all member states are obliged to adhere.

Yet despite this political commitment to the principle of democracy most member states have singularly failed to incorporate that commitment into domestic definitions of terrorism. Although there is no entrenched legal right of democratic governance in international law it is clear that since the end of 
the cold war this principle is evolving into such a right and that the international community has begun to take idea of democratic rights seriously.

\section{The Example of the United Kingdom}

A paradigm example of state failure to fully incorporate recognition of the right of self-determination and or a right to democracy in its definition is the UK and its enactment of the Terrorism Act 2000 (TA). Section 1(1) of the Terrorism Act defines terrorism as the use or threat of action falling within section 1(2) which is designed to influence the government or to intimidate the public or a section of the public for the purpose of advancing a political, religious or ideological cause. It has been held by the Court of Appeal that the word 'government' in s1(1)(b), as explained in s1(4)(d) in relation to foreign governments, is not limited to those countries which are governed by what may broadly be described as democratic or representative principles but includes a dictatorship, or a military junta or a usurping or invading power. Notwithstanding the European Convention's commitment to democracy the Court ruled that $\mathbf{s} 1$ did not specify that the ambit of its protection is limited to countries abroad with governments of any particular type. What was striking about the language ofs1, read as a whole, "is its breadth." 20

The action specified in section 1(2) is action which (a) involves serious violence against a person (b) involves serious damage to property (c) endangers a person's life, other than that of the person committing the action (d) creates a serious risk to the health or safety of the public or a section of the public, or (e) is designed seriously to interfere with or seriously to disrupt an electronic system. The use of an action falling within section 1(2) which involves firearms or explosives, and which is carried out for a political, religious or ideological cause, is terrorism, whether or not it is designed to influence the government or to intimidate the public or a section of the public: section 1(3). Thus, the use of any firearm for a political purpose in a manner which endangers a person's life is terrorism. And the disruption of any electronic system for a political purpose is terrorism, whether or not it is done by violent means. Section 1(4) makes it clear that the action may be an action which takes place outside the United Kingdom, and the government whose actions it is sought to influence may be a foreign government.

The definition adopted in the TA is broader than that adopted in the International Convention (ICSTF). In particular:

(a) The ICSTF definition is confined to the use of violence on civilians and non-combatants.

${ }^{20}$ See Court of Appeal Judgment dated 16/02/07 in $R v F$. Case No: 2007/00579/B5. [2007] EWCA Crim 243. 


\section{TERRORISM, PROSCRIPTION AND THE RIGHT TO RESIST IN THE AGE OF CONFLICT}

(b) It does not include damage to property (other than by bombing).

(c) It does not extend to action which creates a serious risk to health or safety.

(d) It does not include the non-violent disruption of an electronic system.

It follows that the potential range of foreign organisations falling within the definition of terrorism under the TA 2000 is extremely wide. It potentially encompasses almost all organisations engaged in armed conflict around the world, whatever the circumstances, and is wide enough to include organisations which have the political support of the United Kingdom and which would, for that reason alone, not be proscribed (such as the Northern Alliance in Afghanistan).

The power of proscription under section 3 is, however, discretionary. The Secretary of State is not required to proscribe any organisation merely because it meets the statutory test. The judgment which the Secretary of State is called upon to make is an essentially political one but one guided by principle, fairness and a proper examination of the surrounding context. It is plain that the definition of terrorism in section 1 was intentionally overbroad, so as to delegate to the Secretary of State the judgment as to which organisations would, and which would not, be proscribed.

In fact it is noteworthy that the scope of the Secretary of State's discretion is further enlarged by the criteria for proscription. Section 3(3) of the TA provides that the Secretary of State may exercise his power to add an organisation to the list of proscribed organisations in Schedule 2 "if he believes that it is concerned in terrorism." Section 3(5) provides that an organisation is "concerned" in terrorism if it (a) commits or participates in acts of terrorism, (b) prepares for terrorism (c) promotes or encourages terrorism or (d) is otherwise concerned in terrorism.

At first sight, it may appear that the Secretary of State must believe that the organisation is engaged, directly or indirectly, in acts of terrorism as defined in section 1 at the time he proscribes it, or at the very least that it is, at the relevant time, preparing for such acts or promoting or encouraging such acts by others. This appears to be the natural reading of section 3(3) which uses the present tense (“...is concerned in..."). However, section 3(5)(d) establishes an even broader basis for proscription. Even where an organisation is not committing, participating or preparing for terrorism, nor encouraging or promoting such acts by others, it may be proscribed if the Secretary of State believes that it is "otherwise concerned" in terrorism. As regards de-proscription, the Secretary of State interprets this to include a situation in which an organisation is not currently engaged in any of the prohibited forms of conduct, provided he believes or fears that it has engaged in acts of terrorism in the past, and may possibly do so again in the future. 
This interpretation has recently been rejected by the Court of Appeal in the case of The Secretary of State for the Home Department and Lord Alton of Liverpool and others (Case No. 2007/9516).

What is clear is the definition in the UK Terrorism Act 2000 is plainly capable of encompassing organisations that have engaged in lawful armed conflict in the exercise of the internationally recognised right to selfdetermination of peoples. As noted above, the United Kingdom is bound, in international law, to recognise that liberation movements representing certain peoples and organised racial groups have the right to engage in armed conflict in order to realise their legal right to self-determination. And it is bound, in international law, to refrain from offering material support to states engaged in the suppression of the exercise of this right by military or other coercive means. However, the definition of terrorism in section 1 of the Terrorism Act is plainly wide enough to include such movements and organisations. Those who support, or seek to elicit support for legitimate liberation movements, recognised as such under international law, are nonetheless at risk of proscription.

The same is true for any organisation that claims to be resisting an oppressive regime and taking up arms as a last resort in an attempt to establish democratic change. However, as the Court of Appeal made clear in $R v F$ (cited above) the Terrorism Act provides no cover in relation to those who take up arms against oppressive tyrannically regimes even as a legal defence rather than a claim. Take also, for example, the UK proscription of the PMOI, an Iranian resistance movement dedicated to the overthrow of the current regime in Tehran. The UK Secretary of State, in refusing the application to de-proscribe the PMOI, stated:

"The Home Secretary has taken full account of the ...assertion that Mujahedin e Khalq is involved in a legitimate struggle against a repressive regime and has no choice but to resort to armed resistance. He notes too the claim that armed resistance is concentrated against military and security targets within Iran only. The Home Secretary does not, accept, however, any right to resort to acts of terrorism, whatever the motivation..." 21

The reference to acts of terrorism means any use of force. It is simply impermissible for any movement to deploy force against another State in any circumstances including those provided for under international law. One might have reminded the Home Secretary of the preamble to the Universal

\footnotetext{
${ }^{21}$ Right to resist oppressive regimes must be recognised in terrorism legislation. - M Muller - http://mujahedin-e-khalq.org/MEK-MKO/
} 
Declaration of Human Rights (1948) (and its recognition of the rebellion as a last resort) that:

"It is essential, if man is not to be compelled to have recourse, as a last resort, to rebellion against tyranny and oppression, that human rights should be protected by the rule of law."

Yet, the proscription of the PMOI continues despite Former Prime Minister Blair's recent admission on 8 February 2005 that Iran "certainly does sponsor terrorism" and is a deeply repressive regime. Again, it matters not whether this is or is not in fact an accurate description of the Iranian regime. What is striking is the UK Government's desire to proscribe an organisation that does not have as its target any UK interests, and which, in the words of Mr. Blair, is fighting a state sponsor of terrorism. The important point is not whether the UK Government was right to proscribe this particular organisation but its apparent determination to impose a total prohibition on the use of violence whatever the circumstances and however dire the oppression of the group taking up resistance. Given the potential breadth of the Home Secretary's discretion to proscribe surely one aspect of the exercise of this discretion is to have due regard for the principles of international law including the general principles of community law when deciding to proscribe an organisation that falls within the statutory criteria. Thus, even if the definition of terrorism under UK law is broad enough to encompass all organisations that deploy or threaten to deploy violence, the Home Secretary's discretion is likewise broad enough to make exceptions based upon compliance with international obligations.

\section{PROSCRIPTION REGIMES AND THE REINFORCEMENT OF STATE SOVEREIGNTY}

So why do democratic governments such as the UK Government feel it politically necessary to not just define but also strictly apply the definition of terrorism in such a way as to jettison any commitment to democracy or selfdetermination or make any allowance for those foreign movements fighting undemocratic or oppressive regimes or who were engaged in lawful armed conflict in the exercise of the internationally recognised right of the self determination of peoples? Especially in circumstances where the UK routinely expresses its support for the principle of democracy and is bound by international law to recognise the right and to refrain from offering material support to states engaged in the suppression of the exercise of the right by military or other coercive means. 
Why, for example, in March 2001 did the UK Government feel compelled to proscribe 21 organisations together in a "take it or leave it list" without providing parliament with an opportunity to properly consider the individual merits in respect of each group or examine the distinction between terrorist, separatist, resistance, and liberation movements? After all, the UK Terrorism Act 2000 prefigured $9 / 11$ and the subsequent global rise of Islamic fundamentalist insurgency. The 2000 Act was not rushed through parliament as a consequence of any state of emergency. Nor was it was enacted due to massive heightened public anxiety over terrorism. In fact the Terrorism Act came into force a full six months before $9 / 11$ even occurred.

Some argue that the enactments like the UK's Terrorism Act 2000 form part of a politicised process that preceded $9 / 11$ in which many states had effectively resolved between themselves to reinforce the supremacy of state sovereignty at the expense of international law. These states were already increasingly co-operating with each other on a bilateral and sometime multi lateral basis to stop each other's territory from being used by foreign resistance movements, irrespective of whether such movements could be said to be terrorist in nature or merely legitimately defending themselves against attack by an oppressive or racist regime. In short, these states effectively failed to protect the principles of self-determination and democracy within their domestic definitions of "terrorism" as both principles constitute a threat to the power and authority of the nation state and interfered with their respective foreign policies.

That is why many legal commentators have argued that whether a group is on or off a proscription list has more to do with geo politics and diplomatic relations between states than with genuine threats to a particular countries national security and the strict application of law in relation to terrorism. The UN stricture to member states to co-operate in countering terrorism in practice has become intertwined with a whole set of other foreign, military and strategic objectives that govern relations between states. The temptation to offset any strict application of the law relating to fighting counter terrorism in favour of achieving other desirable foreign policy goals is huge. This temptation fundamentally affects the integrity of counter terror legislation and creates real resentment and further resistance within dissident groups who are caught by measures taken on broader policy grounds.

Classic examples include the PMOI, which according to official papers was only proscribed by the Clinton Administration and later by the EU as a "good will gesture" towards Iran when the U.S. was seeking to court the newly elected moderate President Khatami. The European Council's decision to proscribe the PMOI was subsequently challenged in the European Court of Justice. In early 2006 the Court of First Instance declared the original proscription unlawful holding that the Council had breached the applicant's 


\section{TERRORISM, PROSCRIPTION AND THE RIGHT TO RESIST IN THE AGE OF CONFLICT}

procedural rights to a fair hearing and had wholly failed to provide reasons for the proscription. ${ }^{22}$

Back in the UK a group of prominent Lords and Members of Parliament challenged the failure of the Home Secretary to de-proscribe the PMOI on the grounds that it breached fundamental rights and was politically motivated. The application for de-proscription was filed in June 2006. By that time the PMOI had given up its armed struggle for five years, voluntary disarmed its cadres in Iraq, and publicly pledged itself to overthrowing the regime in Tehran through peaceful non-violent means. On $30^{\text {th }}$ November 2007, the Proscribed Organisation Appeals Commission (POAC) gave judgment and declared the proscription unlawful, characterising the position of the Home Secretary as legally "perverse". 23

In April 2008 the Court of Appeal emphatically upheld that ruling. The Court referred to a two-stage test. The first test concerned whether the PMOI met the statutory provision of being "otherwise concerned in terrorism" under s 3(5)(d). The second test concerned whether, having come within the statutory provision, the Home Secretary lawfully exercised his discretion to proscribe or refuse to de-proscribe the PMOI. Both tests required an intense scrutiny of the Home Secretary's belief that the PMOI was "otherwise concerned in terrorism" because proscription interfered with fundamental human rights. In the event, the Court of Appeal upheld POAC's findings as to the nature of the scrutiny to apply and as to its the rulings of fact and law. In particular, it specifically rebutted the Home Secretary's submission concerning the ambit of Section 3(50(d) that it was enough for an organisation to be "otherwise concerned in terrorism" even if it was not currently engaged in promoting, preparing or committing acts of terror, provided it maintained its organisational existence and the Home Secretary entertained a fear that it might use its resources to return to violence in certain unspecified circumstances. In fact what needed to be legally and evidentially demonstrated was that the PMOI was currently engaged in terrorism and/or continued to maintain its organisation for that specific intended purpose. There was no evidence to this effect and nothing less would do. ${ }^{24}$

Another example of a less than perfect legal proscription process concerns the original EU proscription of the $\mathrm{PKK}^{25}$, a radical Kurdish nationalist party

\footnotetext{
22 See Case T-228/02 Organisation des Modjahedines du people d'Iran $v$ Council [2006] ECR II - 4665.

${ }^{23}$ See POAC Judgment of 30/11/07 in Lord Alton of Liverpool \& Others (in the Matter of the People's Mojahadeen Organisation of Iran) $v$ Secretary of State for the Home Department. Appeal No: PC/02/2006

${ }^{24}$ See Times Law Report, 13/05/08 - Court of Appeal Judgment dated 07/05/08 in Secretary of State for Home Department $v$ Lord Alton and Others. Case no: $2007 / 9516$.

${ }^{25}$ Partiya Karkerên Kurdistan.
} 
advocating greater rights for Kurds in Turkey. That organisation found itself proscribed by the EU after repeated requests from Turkey despite having observed a six-year cease-fire during which no acts of violence occurred. In fact the European Council failed to proscribe the PKK in its first proscription list of November 2001 issued just after 9/11 despite having conducted a thorough review of all organisations potentially caught by EU terror provisions. Six months later the European Council proscribed the PKK but only after it had announced its own dissolution and created a successor organisation KADEK, whose alleged purpose was to foster a democratic settlement to the Kurdish Question. Yet quite remarkably the Council failed to proscribe the successor organisation despite regarding KADEK as an alias of the PKK. When the Council did subsequently proscribe the successor organisations KADEK and Kongra-Gel as an alias of the PKK in 2004 it provided no reason for doing so whatsoever.

Many observers find it hard to understand the legal logic of this proscription process. No reasons were ever provided to justify any of these decisions at all. More significantly, there was no explanation as to why, even if the PKK technically came within EU terror provisions, the Council found it legally necessary to exercise its discretion to ban such an organisation at a time when it had given up armed conflict and was ostensibly in search of a non-violent solution. By 2004 the PKK had been on cease-fire for some six years. Some observers suggest the process had more to do with international politics and the need to appease Turkey than with the strict application of law. Apart from the UK, many EU countries initially appeared reluctant to act against the PKK precisely because it was on cease-fire. This state of affairs had substantially assisted the EU accession and reform process within Turkey. Observers suggest this was why the PKK was not banned in November 2001 and only banned in April 2002 after it had dissolved itself and had created a successor organisation.

The PKK subsequently returned to the use of violence after its offer of a non-violent settlement was rejected by Turkey and all of its allied and so called "democratic" successor organisations, like Kongra-Gel, were proscribed by the European Union in 2004. Just whether the proscription regime deployed by the EU actually helped rather than hindered the international fight against terrorism remains a matter of real debate. The recent European Court of Justice's ruling of March 2008 annulling both the original and 2004 proscriptions of the $\mathrm{PKK}^{26}$ and Kongra-Gel for breach of procedural rights and a failure to state reasons by the Council of the European

26 See Case T-229/02 PKK and KNK v Council of the European Community Judgment of 15/02/05 of the European Court of Justice and 03/04/08 of the Court of First Instance of the European Communities. 
Union merely exacerbates this debate. ${ }^{27}$ What is clear is that the lack of procedural and substantive rights afforded to these organisations by the Council of the European Union hardly engendered within those organisations a respect for the rule of law or an acceptance that de-proscription procedures will be applied neutrally and fairly. If anything the manner by which the proscription regime was deployed merely fuelled the PKK's eventual return to violence as all avenues for dialogue were closed.

Thus, to many, the circumstances of the PMOI proscriptions and other EU proscriptions, like the original PKK decision, often appear to have less to do with the strict application of anti-terror provisions and more to do with the need of certain states to get other states to root out unwanted exiled dissident groups. In this process proscribing organisations appear to be traded between states like carbon trading emissions quotas. Thus, in order for certain states to secure certain foreign policy goals, and/or the co-operation of other states in their own fight against indigenous opposition movements, it became necessary to ensure the widest degree of legal latitude and discretion when it came to the business of proscription. That is why little attempt is made by Western powers to protect the right of self-determination or to ensure a right to democracy in terror legislation, despite their own avowed political support for the principle of democracy. Yet, while it might be necessary in terms of "real politic" for western states to afford to themselves a wide legal discretion when deciding to proscribe an organisation or not, there should be no illusion about how the infusion of politics into law by this process has degraded the legal integrity of a number of proscription regimes and actively hindered the ability of third parties and the international community to resolve certain conflicts through peaceful means.

\section{PROSCRIPTION REGIMES AND THE FAILURE TO DEFINE TERRORISM INTERNATIONALLY}

We know from bitter experience that how we label each other has a significant impact upon how we treat each other not just legally but also socially and politically. From US Senator McCarthy's anti-communist list in the 1950's onwards, we have seen time and again just how dramatic and draconian the consequences can be for a person or a group once they becomes designated on a proscribed list. These lists are not just designed to combat criminality. They are designed to de-legitimise certain organisations and their attendant struggles. Proscription regimes are not simply legal tools against

\footnotetext{
${ }^{27}$ See Case T-253/04 Judgment of 03/04/08 the Court of First Instance of Instance of the European Communities in Kongra-Gel and Others $v$ Council of the European Union, United Kingdom of Great Britain and Northern Ireland, Intervener.
} 
terror but ideological and political ones as well. They communicate societies disfavour on the most profound scale.

Accordingly, no one should be in the slightest doubt as to the legal, political and cultural significance of the development of comprehensive proscription "terror lists" in the wake of 9/11. The consequences of proscription are profound and far-reaching. Whether it is the USA Patriot $\mathrm{Act}^{28}$ or the EU Common Position on Combating Terrorism ${ }^{29}$ or the UK Terrorism Act $2000,{ }^{30}$ all use proscription terror lists as a condition precedent to invoking a regime of offences designed to stifle a group's ability to organise, meet and communicate. The purpose of the proscription lists are clear - it is to ostracise, censor, criminalise and silence all those groups that unfortunately find themselves on the list or who are associated with groups or persons on the list.

In conclusion, the failure to agree an international definition of terrorism has had a particularly dangerous impact in field of domestic proscription regimes, the preferred method of combating terrorism around the world. The illegitimate or legally botched use of these proscription procedures is dangerous as it breeds long-term resentment among many exiled dissident groups and communities. The issue is not even whether on the relative merits any of the above named organisations deserve to be legally proscribed. It is the failure of Western states when deciding to proscribe an organisation or not to adhere to fair proscription procedures that are accessible, transparent and apply proportionate legal criteria that have due regard to international law and the protection of fundamental freedoms. The fact that Western States no longer accept that there are any circumstances where a group or unrecognised

${ }^{28}$ The USA response to $9 / 11$ and the UN Security Resolutions is to be found in the USA Patriot Act (United and Strengthening America by Providing Appropriate Tools Required to Intercept and Obstruct Terrorism Act) which was followed on 24 September 2001 by Presidential Executive Order (No. 13224) entitled "Presidential Order Blocking Transactions with Terrorists, which proscribed 100 persons and entities suspected of being connected with terrorism."

${ }^{29}$ The EU response to UNSC Resolution 1373 is to be found in Common Positions of 27 December 2001, 2001/930/CFSP on combating terrorism, and 2001/931/CFSP on the application of specific measures to combat terrorism ([2001] OJ L 344/90), followed by the Council Framework Decision of 13 June 2002, which includes a definition of terrorism ([2002] OJ L 164/3), the Framework Decision on the European Arrest Warrant ([2002] OJ L 190/1), and other measures designed to freeze assets through the blacklisting suspected terror groups or persons. [In the EU proscription, although more symbolic, leads to the potential freezing of assets, and gives a powerful nod to member states to domestically proscribe the relevant organisation or person].

${ }^{30}$ The UK's relevant anti-terror legislation is to be found in the Terrorism Act 2000, which provides for the proscription of terrorist organisations. On 29 March 2001 Parliament passed an Order formally proscribing 21 organisations in a take all of it or live it list. 
people might be forced to have to violence in support of a political objective protected by international law has huge implications for global security and conflict resolution.

\section{A DANGEROUS INTERNATIONAL LACUNA}

Why does all this matter? It matters because, more often than not, the source of violence around the world occurs where there is no democratic outlet for dissent or credible protection for persecuted peoples and minorities. A dangerous political and human rights lacuna has been created in the international legal system. This lacuna consists of the international communities failure to address the position of stateless nations, peoples, and persecuted minorities, and those involved in the collective fight for democratic reform against authoritarian regimes. Instead, member states within the United Nations have preferred to reinforce the virtual inviolability of the system of state sovereignty, save in the exceptional circumstances where the Security Council authorises use of force under Chapter Seven. This lacuna has led to numerous internal conflicts which could have been avoided had certain avenues of international political and legal redress been available. The failure to provide avenues of redress has led numerous groups to turn to more violent methods. The recent swathe of domestic terror legislation simply entrenches this process through its failure to distinguish between terrorism and true resistance in support of democratic change. The attempt to secure international harmony and cooperation through the enforcement of the supremacy of state sovereignty at all costs merely creates more adherents to non-peaceful strategies as dissident groups feel disenfranchised and unfairly punished.

As noted above, the root cause of this remains the continued failure of the international community to reach any agreed consensus about what constitutes terrorism and the outsourcing of the definition of terrorism to member states. As Helena Kennedy QC, the former Chair of the British Council, perceptibly notes:

"Until there is an internationally recognised and sufficiently restrictive definition, it will be hard to have confidence that struggles for selfdetermination and other political activities will not be wrapped up in accusations of 'terrorism'." 31

\footnotetext{
${ }^{31}$ Suspect Communities: The Real "War on Terror" in Europe (London Metropolitan University)

http://www.ejdm.de/Suspect\%20Communitites\%20Conference\%20Report.pdf
} 
Kennedy is surely right when she warns of the danger of "the passing of anti-terrorist legislation against the backdrop of principle."

The United Nations Human Rights Committee has expressed concern about the legislative measures taken by some countries and urged states to ensure that measures undertaken pursuant to resolution 1373 comply with the International Covenant on Civil and Political Rights. More recently, the Council of Europe issued Guidelines of the Committee of Ministers on Human Rights and the Fight Against Terrorism" stating that it is "absolutely necessary, to fight terrorism while respecting human rights, the rule of law and, where applicable, international law." In fact member states of the EU would be wise to recall that the EU note accompanying the draft of the European Framework decision circulated after 11 September 2001 stated that the definition of terrorism does not include "those who have acted in the interests of preserving or restoring democratic values." The Council of Europe Parliamentary Assembly 2008 Report and Resolution on the use of terror lists prepared by its Committee on Legal Affairs and Human Rights (CLAHR), written by Senator Dick Marty, rightly criticised the failure of EU and its states to adhere to principles of legal fairness and international law when enforcing proscription regimes. ${ }^{33}$

In short terror lists should not used as mere instruments of foreign policy without a proper regard for the principles of due process and rights recognised in both of national and international law. Certain persecuted groups allegedly forced to take up violence as a last resort must be given an avenue of redress or at the least, the possibility of raising a legal defence, both procedurally and substantively, to a charge of terrorism, so that any further resort to violence can be rightly condemned as extremist and unlawful by all right thinking nations. Otherwise the application of proscription regimes will hinder rather than help the fight against terrorism and the wider search for peace across the globe.

\footnotetext{
32 Appendix 3 to the Decisions of the Committee of Ministers, adopted at their $80^{\text {th }}$ meeting on 11 July $2002 \mathrm{CM} / \mathrm{Del} / \mathrm{Dec}$ (2002) 804 of 15 July 2002, http://wcm.coe.int/ViewDoc.jsp?id=296009\&lang=en.

33 See Committee on legal Affairs Document 11454 and the Council of Europe Parliamentary Assembly Resolution 1597 (2008) on United Nations Security Council and European Union Blacklists.
} 